\title{
Premature Labor
}

National Cancer Institute

\section{Source}

National Cancer Institute. Premature Labor. NCI Thesaurus. Code C50917.

Regular uterine activity with associated cervical change prior to 37 weeks gestation. 